
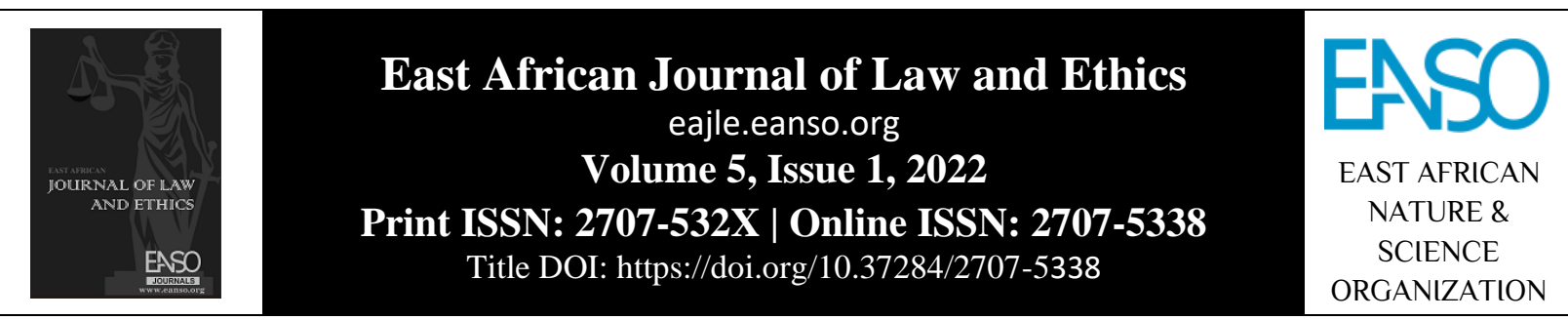

Original Article

\title{
Sentencing Child Offender: Key principles and Substances that the Juvenile Court Needs to Consider in Tanzania
}

\author{
Tundonde S. Mwihomeke ${ }^{1 *} \&$ Rose J. Jally ${ }^{l}$ \\ ${ }^{1}$ Institute of Judicial Administration, P. O. Box 20, Lushoto -Tanga Tanzania. \\ * Author for Correspondence ORCID ID: https://orcid.org/0000-0003-1292-0958; email: tundonde84@ gmail.com
}

Article DOI: https://doi.org/10.37284/eajle.5.1.576

\section{Date Published: ABSTRACT}

08 March 2022 Children commit crimes and they are convicted daily in our courts. Once the court convicts the child as an offender, it must impose correctional measures

Keywords: immediately. The major rationale for handling down the child to correctional mechanisms is to rehabilitate the child offender. Thus, the Juvenile Court is
obliged to maintain and strengthen family relationships, choose a least Key principle, Child Offender, Rehabilitation, Proportionality, Juvenile Court. restrictive sentence which is proportionate to both offence and offender that makes a child offender change and accept his or her responsibilities towards the commission of the offence. The obligation of the juvenile court is well enshrined in international legal instruments which necessitated the introduction of the key principles to be considered in sentencing child offenders in Tanzania. The key principles introduced by the international instruments focus on: rehabilitation of the child offender; maintaining and strengthening family relationships; being least restrictive; be proportionate to the youthfulness of the child; consideration of the interest of the society; and enabling the offender to accept responsibilities over the offence committed. Based on this, the Child Act focuses more on non-custodial sentences; the key principles to consider when sentencing the child are not provided in the Act explicitly rather there presented in its Rules. The present article discusses Case Laws, Statutes provisions and international laws and the legal position in Tanzania regarding the key principles and substances to consider when sentencing a child offender. It further points out the gaps of laws and practices which normally emerge when considering proper sentence to a child offender. It is concluded that laws regarding sentencing child offenders should reflect the international instruments. The courts and other state organs should make sure their practice meets the purpose of sentencing children offenders.

1 | This work is licensed under a Creative Commons Attribution 4.0 International License. 


\section{APA CITATION}

Mwihomeke, T. S. \& Jally, R. J. (2022). Sentencing Child Offender: Key principles and Substances that the Juvenile Court Needs to Consider in Tanzania. East African Journal of Law and Ethics, 5(1), 1-12. https://doi.org/10.37284/eajle.5.1.576

\section{CHICAGO CITATION}

Mwihomeke, Tundonde S and Rose J. Jally. 2022. "Sentencing Child Offender: Key principles and Substances that the Juvenile Court Needs to Consider in Tanzania". East African Journal of Law and Ethics 5 (1), 1-12. https://doi.org/10.37284/eajle.5.1.576.

\section{HARVARD CITATION}

Mwihomeke, T. S. \& Jally R. J. (2022) "Sentencing Child Offender: Key principles and Substances that the Juvenile Court Needs to Consider in Tanzania", East African Journal of Law and Ethics, 5(1), pp. 1-12. doi: 10.37284/eajle.5.1.576.

\section{IEEE CITATION}

T. S. Mwihomeke, \& R. J. Jally. "Sentencing Child Offender: Key principles and Substances that the Juvenile Court Needs to Consider in Tanzania”, EAJLE, vol. 5, no. 1, pp. 1-12, Mar. 2022.

\section{MLA CITATION}

Mwihomeke, Tundonde S \& Rose J. Jally. "Sentencing Child Offender: Key principles and Substances that the Juvenile Court Needs to Consider in Tanzania". East African Journal of Law and Ethics, Vol. 5, no. 1, Mar. 2022, pp. 1-12, doi:10.37284/eajle.5.1.576.

\section{INTRODUCTION}

In Tanzania, a person is considered a child offender if he/she is convicted of an offence punishable under the law while is below the age of eighteen (18) years. ${ }^{1}$ The Tanzanian courts have for many years advocated for a child offender to be treated differently from adults and to consider the youthfulness of the child for the best interest of the child in order to avoid sentences that might expose the child to interact with criminals. ${ }^{2}$ Whatever the actual practice, sentencing principles for child offenders changed fundamentally with the adoption and domestication of international instruments.

The international legal instruments appeal for the introduction and consideration of the key principles ${ }^{3}$ in sentencing a child offender in Tanzania.The key principles introduced focus on rehabilitation of the child offender; ${ }^{4}$ maintenance and strengthening family relationships, being least restrictive, proportionate to the youthfulness of the child, and respecting the interest of the society as well as enabling the offender to accept

\footnotetext{
${ }^{1}$ Section 4 of the Law of Child Act Cap 13 R.E 2019

${ }^{2}$ R V. Asia Salum and Another (1986) TLR 12, it was held that "Youthful offenders should not be sentenced to terms of imprisonment. Also the case of R v. John s/o Gilied (1984) TLR 273 , provided the same nature of principles in sentencing the juvenile offender.

${ }^{3}$ Article 37,40 of the Convention on the Rights of the Child 1989 (CRC)
}

responsibilities over the offence committed Tanzania has enacted the children's Child Act ${ }^{5}$ which subsumes such principles. In this regard, the law focuses more on non-custodial sentences. ${ }^{6}$ However, the key principles to consider when sentencing the child are not explicitly provided in the enacted Child Act rather in its Rules.Discussing the context on key principles and aspects to consider when sentencing a child offender in Tanzania is the most crucial aim of this work. The various key principles and aspects under Rule 49 of the Juvenile Court Procedure Rules, 2016(JCR) are evaluated in relation to the international legal instruments. Subsequently,gaps in laws and practice are raised and orated for solutions.

\section{KEY PRINCIPLES IN SENTENCING A CONVICTED JUVENILE OFFENDER}

\section{Proportionality}

The proportionality principle emanates from international legal instruments. The Convention on

${ }^{4}$ Brian R. Suffredini, Juvenile Gunslingers: A Place for Punitive Philosophy in Rehabilitative Juvenile Justice, 35 B.C. L. Rev. 885 (1994).

${ }^{5}$ Child Act Cap 13 R.E 2019

${ }^{6}$ Part IX of the Law of the Child Act Cap 13 R.E 2019

2 | This work is licensed under a Creative Commons Attribution 4.0 International License. 
the Rights of the Child, 1989 (CRC) provides to the child the right to non-discrimination, the best interest of the child to be a primary consideration, right to be heard, right to life, right for survival, and development. ${ }^{7}$ This means that the CRC aims at protecting a child by considering the child's basic rights against all actions affecting the affairs of the child.This concept under the CRC draws the "principle of proportionality", which requires the administration of juvenile justice to aim at ensuring all children are dealt with in a manner appropriate to the child's wellbeing and proportionate to the circumstances of both the offender and the offence as it is well enshrined in the CRC. ${ }^{8}$

Despite the fact that the principle of proportionality is well stipulated in different international legal instruments including the $\mathrm{CRC}^{9}$, the Law of the Child Act does not expressly abide by the principle. However, in the reading of the provision of the Law of the Child Act, it is noted that the principle of proportionality is subsumed in the Act. This is different from the Juvenile Court Procedure Rules, which under Rule 49 expressly provides the principle of proportionality. Rule 49 states:

"The court shall, before reaching a decision on the appropriate sentence for convicted child, have regard to the following principles-

- The need for proportionality by reference to the circumstances of both the offence and the offender".

Therefore, before the Juvenile Court makes its decision on the appropriate sentence for a convicted child, the court should consider the "principle of proportionality", for which it must make reference to the circumstances of the offender, offence, and society. In doing so, the court takes into account the seriousness of the offence or offences as well as mitigating factors that are personal to a child or that led to the commission of an offence.

The practice shows that the principle of proportionality has been applied by Tanzanian

\footnotetext{
${ }^{7}$ The underpinning principles in the Convention on the Rights of the Child are: Right to non-discrimination (Article 2), Best interest of the child shall be a primary consideration (Article 3.1), Right to life, survival and development (Article 6) and Right to be heard (Article 12).
}

Courts for many years even before the enactment of the Law of the Child Act and the Juvenile Court Procedure Rules as required by international standards.In R. v. Asia Salum and Others ${ }^{10}$, the appellants (mother and her 17-year-old son) were convicted of assault causing actual bodily harm. The trial court sentenced the accused to twelve months imprisonment. On appeal, the Appellate Court took into its shoulders the principle of proportionality when considering the circumstances of the second offender (the child). In due cause, the following matters were found important to be considered before the imposition of a sentence:

- The offender was a form three student,

- The offender was aged 17 years old,

- The offender was a first-time offender,

- The offender was badly injured,

- The nature of the offence in regard to the age of the offender,

- Contributory of the offender in the commission of the offence,

- Perception of society to the offender in the commission of the offence.

The court considered all these factors based on the principle of proportionality and concluded that imprisonment was not a favourable sentence to the juvenile offender since sending him to prison might spoil the child's behaviour as he would be in contact with criminal offenders. The court further opined that the proper sentence to this kind of juvenile offender was a probation order or absolute discharge.

Contrary to the above credits, there are some recent case laws that failed to cogitate this key principle when sentencing child offenders. In Mohamed

\footnotetext{
${ }^{8}$ Article 37 CRC

${ }^{9}$ Ibid above

${ }^{10}$ R. v. Asia Salum and Others( (1986) TLR 12
} 
Hamis V. $\mathrm{R}^{11}$, the appellant who raped a child of five years was charged and convicted of the offence of rape. The trial court sentenced the accused person to life imprisonment pursuant to section 131 (3) of Cap 16. ${ }^{12}$ After his appeal to the High Court failed, he appealed to the Court of Appeal.The Court of Appeal held that:

"The accused person committed the offence when he was sixteen (16) years old, being the first offender, he could be sentenced as per section 131 (2) (a) of the penal code. Sentence awarded as per section 131 (3) of the Penal Code ${ }^{13}$ is Illegal".

In this case, the Court of Appeal of Tanzania considered the accused age, the accused being the first offender and the seriousness of the offence committed and declared the sentence imposed by the trial court being illegal. The Court of Appeal at last imposed the corporal punishment sentence.

Considering the case above, although the trial court sentenced the accused to life imprisonment, the High Court, in the cause of determination of the appeal, sustained the sentence due to the fact that the appellant was a child. Thus, the High Court was supposed to consider the nature of the offence and the youthfulness of the child.Consequently, the Court of Appeal struck the sentence and replaced it with corporal punishment. ${ }^{14}$ Corporal punishment is a sentence which does not consider a strong mitigating factor of youthfulness. The imposition of corporal punishment by the Court of Appeal shows that the court did not take into account the principle of proportionality in relation to the welfare of the accused by considering his youthfulness.Again, the imposition of corporal punishment infringed some of the rights entitled to a child in conflict with the law. ${ }^{15}$ Corporal punishment is as well a non compliance with the international child legal

\footnotetext{
${ }^{11}$ Mohamed Hamis V. R Criminal Appeal 114 of 2013 Court of Appeal of Tanzania at Mtwara (unreported)

${ }^{12}$ Penal Code R.E 2002

${ }^{13}$ Ibid ( above)

${ }^{14}$ Section 131(2) (a) of the Penal Code CAP.16.

"Notwithstanding the provisions of any law, where the offenceis committed by a boy who is of the age of eighteen years or less, he shall- (a) if a first offender, be sentenced to corporal punishment only;"
}

instruments ratified by our country. ${ }^{16}$ It is worth noting here that even where the offence is of a serious nature,the circumstances of the offender need to be considered by the court in order to craft a proper sentence.

Exploring other jurisdictions on crafting of sentence to a child offender convicted of a serious offence shows that courts have been striking a balance between the youthfulness of the offender and the seriousness of the offence committed. In the case of Frederick ${ }^{17}$,the accused child,aged 14 was charged with the offence of robbery by using a firearm and a knife whilst raping a child aged 16 years.In this case, the court provided that:

"While the gravity of the offences requires a severe sentence with strong deterrent and retributive elements, the youthfulness of the appellant required a balanced approach reflecting an equally strong rehabilitative component. Appreciating the fact that the appellant was an immature youth merely 14 years old at the time he committed the offence".

The court in this case balanced between child youthfulness as "a strong mitigating factor" and the seriousness of the crime he committed, which calls for severe punishment of the offender with a view to preventing re-occurrence. Out of this balance, the court lowered the sentence and provided a sentence that focused on rehabilitating the child offender.

Learning from the case of Fredrick from the South African Court,it is proper for Tanzania Courts to balance child youthfulness as a strong mitigating factor to the seriousness of the offence committed during the sentencing processes meanwhile adherence to other relevant principles. The outcome of considering all such factors during the imposition of sentences leads to protection of the principle of

\footnotetext{
${ }^{15}$ Section 13 of the Law of Child Act R.E 2019

16 The provisions against corporal punishment are found in Article 7 of the International Covenant on Civil and Political Rights, Article 37 of the Convention on the Rights of the Child and the Declaration on the Protection of All Persons from Being Subjected to Torture and Other Cruel, Inhuman or Degrading Treatment or Punishment, as well as the Convention against Torture and Other Cruel, Inhuman or Degrading Treatment or Punishment.

${ }^{17}$ Frederick v S Case No. 208/ 2011(S.C.A)
} 
proportionality and upholding the primary principle of the best interest of the child offender.

It is fundamental to note that upholding the principle of proportionality to the child offender convicted of a serious offence is a very delicate task. This is because, when considering the sentence, attention to a child is not done in vacuity; all other factors such as its impact on the victims and interest of the broader society must be considered. These are normally considered by the court to the extent that courts impose severe sentences contrary to the directives of the international legal instruments. It is difficult to strike a balance of all these factors which conflict with each other unless a deep purposive interpretation of each criterion is legally considered.

Normally, the principle of proportionality has a number of demands to consider in sentencing. When the court adopts the proportionality while sentencing, among other things, it should consider are the individual circumstances of the offender to include social status, family situation, the harm caused by the offence or other factors affecting personal circumstances. Likewise, it has to consider the influence of the reactions,such as the offender's endeavour to indemnify the victim or willingness to turn to a wholesome and useful life. By the same token, reactions aiming to ensure the welfare of the young offender may go beyond necessity and therefore infringe upon the fundamental rights of the young individual, as have been observed in some juvenile justice systems. Here too, the proportionality of the reaction to the circumstances of the offender, of the society and including the victim, should be safeguarded.

\footnotetext{
18 Article 10, paragraph 1, of the International Covenant on Economic, Social and Cultural Rights

${ }^{19}$ Wright, K N and Wright K E, Family life, Delinquency and Crime: A Policymaker's Guide. Research Summary, U.S Department of Justice, 1994.

${ }^{20} \mathrm{UN}$ Guidelines on the prevention of the Juvenile Delinquency (Riyadh Guidelines), Guideline12. The family is the central unit responsible for the primarysocialization of children, governmental and social efforts to preserve the Integrity of the family, including the extended family, should be pursued. The society has a responsibility to assist the family in providing care and protection and in ensuring the physical and mental well-being of children.
}

\section{Maintaining and Strengthening Family Relationships}

Family and community are core units bestowed with important roles in the development of the life of every child. ${ }^{18}$ Maintaining and strengthening family relationships,therefore, is among the key principles a Court needs to consider before imposition a proper sentence on the convicted child offender.

The family is the foundation of human society. ${ }^{19}$ Socialisation in the family is very important,especially between parents and children. The relationships between children and their parents are legally protected to create an environment for children to learn from the parents and society in general. ${ }^{20}$ The learning techniques of social living have both positive and negative traits.Supporting this is Moffitt (1993)stresses that the antisocial behaviours of adolescents are learnt through the process of social mimicry. The child who is in a good family and a good community mighty be grown in good behaviour. However, if the child is exposed to a bad environment, the child will learn and demonstrate deviant behaviour. Therefore, maintaining and strengthening the family relationship of a child is crucial to the positive wellbeing of a child towards attaining adulthood. ${ }^{21}$ This position is well protected by international legal instruments. Article 8 of $\mathrm{CRC}^{22}$ provided that:

"States Parties undertake to respect the right of the child to preserve his or her identity, including nationality, name, and family relations

${ }^{21}$ If the nature of socialization is so commanding, strict and threatening, children may adopt hostility behaviour (Broom, 1968) and sometimes they become delinquents. Accordingly to the study results explored that, father's interaction with the family is important especially on maturity period of the boys. Moreover, fathers who are not highly aggressive interact with their wives in a highly mutual way provide models for socialized behaviour. Contrary to this, fathers who are aggressive and fight with their families provide models of antisocial behavior (McCord, 1991) a factor which contributes to the increase of crimes is family relationships. McCord (1991) Family Relationships, Parent Interaction to Their Children has Influence on Delinquency.

${ }^{22}$ Convention on the Right of the Child, 1989 
as recognised by law without unlawful interference".Emphasis added

The above international legal provision requires the establishment of a conducive environment within States, which will strengthen family relations to the extent of making children live with their families. The Convention further provides that every child deprived of his liberty shall have the right to maintain contact with his or her family through correspondence and visits. The latter statement saves in exceptional circumstances. ${ }^{23}$ Concentrating on the phrases in italics, States parties have an obligation to respect and maintain every child's rights to family relations even when a child is in conflict with the law. In such circumstances, the liberty and the right of the child to interact with his family members have to be prioritised. The Beijing Rules $^{24}$ prescribes that the removal of a juvenile from parental supervision, whether partly or entirely, should only be done by lawful authorities in necessary circumstances. This position has been reaffirmed under Article 19 of the ACRWC ${ }^{25}$ when prescribing that:

"Every child shall be entitled to the enjoyment of parental care and protection and shall, whenever possible, have the right to reside with his or her parents. No child shall be separated from his/her parents against his/her will, except when a judicial authority determines in accordance with the appropriate law, that such separation is in the best interest of the child".

The provision above restricts the child from being separated from his/her family members except by due judicial process. However, even the judicial process should do so for the best interest of the child. Therefore, the separation of children from their parents has to be done as a matter of last resort considering the importance of the family as

\footnotetext{
${ }^{23}$ Article 37 (c )Convention on the Right of the Child, 1989

${ }^{24}$ Rule 18 of United Nations Standard Minimum Rules for the Administration of Juvenile Justice (Beijing Rules)

${ }^{25}$ African Charter on the Rights and welfare of the Child ,1999

${ }^{26}$ Article 10, paragraph 1, of the International Covenant on Economic, Social and Cultural Rights 1966

${ }^{27}$ Section 7(1) and (2) of the Law of the Child Act Cap 13 R.E of 2019
}

prescribed in the International Covenant on Economic, Social and Cultural Rights ${ }^{26}$ and explained above.

The Law of the Child Act recognises the essence of maintaining and strengthening family relationshipswithall children, even in the field of criminal justice. Section 7 provides that: ${ }^{27}$

"(1) A child shall be entitled to live with his parents or guardians,

(2) A person shall not deny a child the right to live with his parents, guardian or family and grow up in a caring and peaceful environment unless it is decided by the court that living with his parents or family shall - (a) lead to a significant harm to the child; (b) subject the child to serious abuse; or (c) not be in the best interest of the child".

Regarding the position of law provided above, the Law of the Child Act conforms to the position provided in the international legal instruments that the child has to be with his/ her family unless by the authority of the court.

Therefore,the Law of the Child Act ${ }^{28}$ and Juvenile Court rules ${ }^{29}$ protect the rights of the child to live with his/her family members, especially his or her parents, unless when maintaining the relationship of the child to parents is exposing the child to ill behaviours or is not generally for the best interest of the child. The protection provided under the $\mathrm{Act}^{30}$ clearly extends even to a child in conflict with the law. To emphasise this, the Juvenile Court Rules $(\mathrm{JCR})^{31}$ precisely emphasises that the juvenile court consideration of maintaining family relationships between a child and family members is a crucial principle in sentencing. Therefore, when a custodial sentence is imposed on a child offender, his/her rights to interact and maintain family

${ }^{28}$ Section 7,112 and 132 of the law of the Child Act Cap 13 R.E of 2019

\footnotetext{
${ }^{29}$ Rule 49 (1) paragraph C of the Law of the Child Act (Juvenile Court Procedure) 2016

${ }^{30}$ Law of the Child Act R.E 2019

${ }^{31}$ Rule 49 (1) paragraph C of the Law of the Child Act (Juvenile Court Procedure) 2016
}

6 | This work is licensed under a Creative Commons Attribution 4.0 International License. 
relationships should be sustained.However, the instruments do not provide how the collaboration of parents and official agencies will take place to maintain and strengthen family relationships with the child who is separated from the parent lawfully. ${ }^{32}$ As a result, most of the parents do not visit their children whilst detained in different places such as approved schools because of lack of funds or long distance as there is only one approved school in Tanzania. Thus, after the completion of serving a sentence, children lose their initial strong bond with their families. For example, the law allows the court to order the child to custody if he or she commits an offence for which, if committed by an adult, would have been a custodial sentence. ${ }^{33}$ The law, however, does not prescribe effective mechanisms to make sure the child maintains family relationships during the period of detention. ${ }^{34}$

It has been noted that the court in Tanzania, despite imposing the approved school as a last resort and the only custodial sentence,the court imposes the custodian sentences regardless of other considerations of the principle for maintaining and strengthening a family relationship. This conclusion is drawn from the research findings ${ }^{35}$ that show that most of the children in approved schools have no contact with their family members. Thus, courts have to foresee the likelihood of breakage of family relationships between the child and his family. The courts need to refrain from committing the children to approved school save for the best interest of the child.

\footnotetext{
32 Adam S. W The role of integrated approach to addressing juvenile delinquency in Tanzania: A case Study of Ilala Municipality Masters in social work dissertation, Open University of Tanzania $2017 \mathrm{pg} 6$.

${ }^{33}$ Section 120 of Law of the Child Act Cap 13 R.E of 2019

${ }^{34}$ Section 132 of Law of the Child Act Cap 13 R.E of 2019

${ }^{35}$ Commission for Human Rights and Good Governance,Inspection Report for Children in Detention Facilities in Tanzania June 2011

${ }^{36}$ Article 17(3)of the African Charter on the Rights and welfare of the Child
}

\section{Rehabilitating and Reintegrating Child Offenders}

Rehabilitation and reintegration of a child offender are based on helping the child to be a legitimate member of society with the rights and responsibilities of a citizen. In other words, the goal of every phase of the juvenile justice system must be to rehabilitate ${ }^{36}$ and reintegrate the juvenile offenders successfully back into the community and to help them lead constructive lives in future. ${ }^{37}$

The Convention on the Rights of the Child, to which Tanzania is also a state party, ${ }^{38}$ requires the domestic juvenile court to take into consideration the principle of rehabilitating and or reintegrating a child in the society whilst sentencing. In Article 40(1) of the CRC,it is stipulated as follows: ${ }^{39}$

"States Parties recognise the right of every child alleged as, accused of, or recognised as having infringed the penal law to be treated in a manner consistent with the promotion of the child's sense of dignity and worth, which reinforces the child's respect for the human rights and fundamental freedoms of others and which takes into account the child's age and the desirability of promoting the child's reintegration and the child's assuming a constructive role in society".

The CRC general comment No. $10^{40}$ reminds States parties that the reintegration requires that no action may be taken to hamper the child's full participation in his community, such as stigmatisation, social isolation, or negative publicity of the child. ${ }^{41}$ Therefore, a child in conflict with the law should be dealt with in a way that supports the child becoming a full, constructive member of society. Where it is necessary to impose a custodial

${ }^{37}$ N Kilekamajenga Referral Mechanisms for Restorative Justice in Tanzania, South Africa Crime Quarterly No. 63 March 2018

${ }^{38}$ Tanzania ratified the Convention on $10^{\text {th }}$ June 1991, two years after being opened for signature.

${ }^{39}$ Convention on the Rights of the Child, 1989

${ }^{40}$ CRC Committee: General Comment No 10, 2007, paragraph 29

${ }^{41}$ The Convention on the Rights of the Child, Article 40(1)

7 | This work is licensed under a Creative Commons Attribution 4.0 International License. 
sentence on a convicted child, Rule 26 (2) of the Beijing Rules states:

"Juveniles detained in facilities should be guaranteed the benefit of meaningful activities and programmes which would serve to promote and sustain their health and selfrespect, to foster their sense of responsibility and encourage those attitudes and skills that will assist them in developing their potential as members of society”.

In order to better comprehend the above international standards, one must briefly note that on awarding a sentence, whether custodial or noncustodial,rehabilitation and reintegration of the offender into the society is a crucial principle to consider. In Tanzania, the principle that the offender child should be granted a sentence that rehabilitates and reintegrates him or her into society has since $R$. v. Asia Salum and others ${ }^{42}$ been considered as part of the law. In this case,the accused mother and her 17year-old son were convicted of assault, causing actual bodily harm. Both were first offenders and were each sentenced to twelve months' imprisonment. The record of the proceedings was called by the High Court for satisfying itself as to the correctness, legality and the propriety of the sentences imposed. Mnzavas JK (as he then was) held that:

- Where a first juvenile offender is concerned, the emphasis should always be on the reformative aspect of punishment;

- First juvenile offenders should not, as a rule, be sent to prison where there is an opportunity to mix with and learn bad habits from more seasoned criminals.

This case was intended to be a catch-all case to subordinate court to adhere to the principle of

\footnotetext{
${ }^{42}$ R. v. Asia Salum and Others (1986) TLR 12(The case has been also referred in the above principle of proportionality)

${ }^{43}$ R V Hamidu Athuman @ Matata Criminal Revision 2of 2019 High Court of Tanzania at Mtwara (Unreported case).

${ }^{44}$ Section 131(2) of the Penal Code Cap 16 R.E 2019.

${ }^{45}$ Geer 2008 Dev Mental Health L 33-52.

${ }^{46}$ Geer 2008 Dev Mental Health L 41.
}

rehabilitating and reintegrating first-child offenders. The case law is old. However,the legal position is adamant regarding sentencing juvenile offenders to rehabilitative sentences.Nevertheless, the rule is not uniformly applied by all superior courts when sentencing child offenders. In the case of $\mathrm{R} \mathrm{V}$. Hamidu Athuman ${ }^{43}$, upon revision, the High Court upheld the sentence of corporal punishment awarded by the trial court. Although this sentence is provided by the Penal Code ${ }^{44}$, it is the sentence that neither aims at rehabilitating the child offender nor reintegrating him into society. Furthermore, the researchers suggest that juvenile sex offenders have a generally lower overall recidivism rate for sexual offences than adult sex offenders. ${ }^{45}$ Due to this, juvenile sex offenders also have more potential for rehabilitation programmes specifically tailored for juvenile offenders. ${ }^{46}$ For this reason, section $131(2)^{47}$ of the Penal Code should be amended and be given a different punishment that considers key principles when sentencing a child. In a South African case of $\mathrm{S} v$. Jansen, ${ }^{48}$ the court held that:

In sentencing the juvenile offender, it is necessary to consider appropriate form of punishment in the peculiar circumstances of the case. It is important for the court to serve the interests of society as well as the best interests of the juvenile. The interests of the society cannot be served by disregarding the interests of the juvenile, for a mistaken form of punishment might easily result in a person with a distorted personality being eventually returned to society.

It is also important to note that, despite the fact that the rehabilitation and reintegration principles have been set by the case law for more than 36 years, when sentencing a child offender, the Child Act does not expressly provide for this principle;the principle is only provided in its Rules. ${ }^{49}$ It is argued that this gap leads to juvenile courts imposing a sentence which are neither rehabilitating nor

\footnotetext{
47 Penal Code Cap 16 R.E 2019 Section 131 (2) Notwithstanding the provisions of any law, where the offence is committed by a boy who is of the age of eighteen years or less, he shall- (a) if a first offender, be sentenced to corporal;

${ }^{48} \mathrm{~S}$ v Jansen 1975 (1) SA 425 (A) at 427H-428A, See also S v B 2006 (1) SACR 311 (SCA), paragraphs. 19-20

${ }^{49}$ Juvenile Court rule 2016
}

$8 \mid$ This work is licensed under a Creative Commons Attribution 4.0 International License. 
reintegrating a child offender. For this reason, the Child Act should be amended to include rehabilitation and reintegrating child offenders into society as principles to be considered on sentences.

Therefore, it is acknowledged that, although the general purpose of sentencing is to deter, punish and prevent the re-occurrence of crimes in society when it comes to child offenders, rehabilitation seems to be emphasised and that children are legally protected by both international ${ }^{50}$ and in part by domestic law. ${ }^{51}$ Education and vocational training are essential to a child's rehabilitation process, as well as psychosocial support to address the root causes of child offending behaviour and reintegrating a child offender into the society.

\section{Least Restrictive}

Sentences for child offenders ${ }^{52}$ have for many years been more lenient than those directed to adults. ${ }^{53} \mathrm{In}$ all proceedings concerning an accused child, upon conviction and when sentencing, our courts have often recognised that child offenders should be afforded with special treatment. ${ }^{54}$ The principle of least restrictive in the imposition of sentences has been enshrined in the JCR. ${ }^{55}$ In Rule 49 of JCR, the rationale of the least restricts principle provides that:

\footnotetext{
${ }^{50} \mathrm{CRC}$, CRC General Comment No. 10, and Beijing Rules.

${ }^{51}$ Rule 49 paragraph (b) of the Juvenile Court Rules 2016

52 Since long time, categories of young offenders were specifically addresses in our law. For example before its repeal, the Children and Young Persons Ordinance, Cap 13 R.E 2002 had specific provisions for" young offenders" persons under the age of 18 years.

${ }^{53}$ In the past, young offenders were specifically addressed in our law leniently. Section 131(2) paragraph (a) of the Penal Code provided lenient punishment of the sexual first offender as compared to Section 131 (1)which prescribed for punishments of sexual first offender adults. In South Africa, the recognition that Children accused of committing offences should be treated differently to adults is now over a century old. Some of earlier judgments on this include R v Smith 1922 TPD 199.

${ }^{54}$ MMN (Child) v R, Criminal Appeal 173 of 2019 High Court of Tanzania at Musoma (unreported). It was held that Law of the Child Act, 2009 (Act No 13 of 2009) overrides other laws when it comes to issues relating to children; so where a child has been charged with sexual offence, the determination of the
}

\section{"The desirability of imposing the least restriction sentence has to be consistent with the legitimate aim of protecting the victims and the community".Emphasis added}

This provision requires the court to opt for minimum punishment meanwhile protecting the interests of the victims and the community at large. ${ }^{56}$ This is because the victim and the community may wish for severe punishment to be awarded to the perpetrator. However, the accused child, due to his/her age, physical and mental immaturity, needs to be afforded with the least restrictive correction measures. Thus,during sentencing the child offender,the court needs to consider all the circumstances of the accused, victims and community to impose the least restrictive accorded measures.

The context provided under rule 49 of $\mathrm{JCR}^{57}$ conforms to the international legal instruments such as the $\mathrm{CRC}^{58}$ and the Beijing Rules ${ }^{59}$, which set out the minimum sentencing standards to child offenders. The instruments premise around two important sets of standards: firstly, principles that provide the aims of sentencing; and, secondly, principles that set out restrictions on sentences to be imposed on children. Despite the fact that international legal instruments and the JCR conform to the principle of least restrictive measures to a

age of the accused child is important because age has implication on the sentence to be imposed.

${ }^{55}$ Juvenile Court Rules, Rule 49 paragraph (d)

${ }^{56}$ This was well observed in the case of Napier C.J. in Webb v O'Sullivan (1952) SASR 65 at 66 says;

"The courts should endeavour to make the punishment fit the crime and the circumstances of the offender, as nearly as may be. Our first concern is the protection of the public, but, subject to that, the court should lean towards mercy. We ought not to award the maximum which the offence will warrant, but rather the minimum which is consistent with a due regard for the public interest." (From other jurisdiction and old case but still relevant on pint of law)
${ }^{57}$ Ibid(above)
${ }^{58}$ Article 40(1) of the Convention on the Rights of the Child( CRC)

${ }^{59}$ Rule 17 of United Nations Standard Minimum Rules for the Administration of Juvenile Justice ("The Beijing Rules") Adopted by General Assembly resolution 40/33 of 29 November 1985 
child offender,but the Tanzania Law (the Child Act $)^{60}$ doesnot precisely mention the principle of least restrictive. It does so by subsumes method because the JCR is made under the Act. The Law of the Child Act practices the least restrictive principle when it bans the imprisonment sentence to the child offender. ${ }^{61}$ Also,it embraces the principle of parsimony which is based on the principle of liberty. That is to say, an offender should not be deprived of liberty if there is least restrictive appropriate sentence. ${ }^{62}$ Considering this, the Act provided for non-custodial sentences to be awarded to child offenders and approved school should be awarded as a last resort.

\section{SOCIAL ENQUIRY REPORT}

The Law of the Child Act (Juvenile Court Procedure) rules provides clearly that the juvenile court has to require the social welfare report before imposing a sentence on the convicted juvenile offender. Despite the fact that the social inquiry report is not among the key principles, it is an essential substance to be considered by the juvenile court when crafting a sentence for a child offender. Principally, the social inquiry report is a report which is prepared by the court social welfare officer. The social inquiry report normally contains details of the child, including the child's background and other material circumstances likely to be of assistance to the court during sentencing. Such substances include: present family circumstances and the home life experienced by the child, the child's attendance to a school or any training programme or employment, the child's state of health, any previous offences the child may have committed, assessment of the chances of the

\footnotetext{
${ }^{60}$ Law of the Child Act cap 13 of R.E 2019

${ }^{61}$ Section 119 of Law of Child Act Cap 13 of R.E 2019

${ }^{62}$ Rule 2 of the UN Rules for the Protection of the Juvenile deprived of their liberty, adopted by General Assembly resolution 45/113 of 14 December 1990 "Juveniles should only be deprived of their liberty in accordance with the principles and procedures set forth in these Rules and in the United Nations Standard Minimum Rules for the Administration of Juvenile Justice (The Beijing Rules). Deprivation of the liberty of a juvenile should be a disposition of last resort and for the minimum necessary period and should be limited to exceptional cases. The length of the sanction should be determined by the judicial authority, without precluding the possibility of his or her early release."
}

child reoffending or causing serious harm, and recommendations on the appropriate sentence, taking into account the purposes of a sentence such as rehabilitation and the rationale of assisting the child to be a constructive member to his/her family and community. ${ }^{63}$

Social inquiry reports are indispensable aid in most legal proceedings involving juveniles. ${ }^{64}$ This is because they provide relevant facts about the juvenile to a competent court. International legal instruments require that juvenile court, before reaching the final disposition of a sentence, has to consider the background and circumstances in which the juvenile is living or the conditions under which the offence has been committed. To reach this position, the court needs to consider the report of the investigation on the welfare of the child so as to facilitate judicious adjudication of the matter. ${ }^{65}$

The Law of Child Act provides that the Juvenile Court may, during the proceedings, where it considers necessary, seek the opinion and recommendation from the social welfare officer. ${ }^{66}$ The Act further provides that where the court seeks for social welfare officer opinion, it shall consider such opinion or recommendation before passing sentence. The provision states:

"Where the court considers necessary to have the opinion or recommendation of a social welfare officer, the court shall consider such opinion or recommendation before passing the sentence". ${ }^{67}$

The provision above does not make mandatory that the opinion or recommendation of a social welfare officer be presented to the court before passing a

\footnotetext{
${ }^{63}$ Rule 47, Law of the Child Act (Juvenile Court Procedure) 2016

${ }^{64}$ Cyrus Tata et al 'Assisting and advising the sentencing decision process: The pursuit of 'quality' in pre-sentence reports' (2008) 45 British Journal of Criminology 835,836.

65 Rule 16, United Nations Minimum Rules for the Administration of Juvenile Justice (Beijing Rules), G.A. res 40/33, 1985

${ }^{66}$ Section 100A (1)

${ }^{67}$ Law of the Child Act, Section 100A (2),
} 
sentence.However, the law makes it mandatory that when the opinion or recommendation of a social welfare officer has been submitted, it is mandatory that the report should be considered. This assertion provides practical challenges: Does the opinion or recommendation referred to in that section qualify to be a social Inquiry report? ${ }^{68}$ In which circumstances it is necessary to consider the social inquiry report? Unfortunately, the Law of the Child Act does not provide clear answers to these questions. The international legal instruments have taken the proper directions in answering the above questions when they provide that:in all serious offences involving the child, the court should consider the social inquiry report before passing sentence. ${ }^{69}$ This is because these instruments aim at providing crucial facts for which it is vital, especially when dealing with a child who faces serious offence. The international legal position has been reiterated under Rule $49(2) .{ }^{70}$ The rule clarifies that the juvenile court before passing sentence has to take into account, among others, the child social welfare stipulated in the social enquiry report. The interpretation of the rule is stronger and wider than the Act. This is because it makes it mandatory that the social inquiry report has to be presented in all serious and minor offences. This is interesting as a rule should reflect the Act in its conceptual context.In this context, the Act has to embrace the concept provided in the rule because it establishes a proper mechanism for the protection of the rights of the child in conflict with the law.

One may consider the South Africa case of $\mathrm{S} \mathrm{v}$ Jansen ${ }^{71}$ where Botha, JA, held that:

"To enable a Court to determine the most appropriate form of punishment in the case of a juvenile offender, it has become the established practice in the Courts to call for a report of the offender by a probation officer in, at least, all serious cases".

\footnotetext{
${ }^{68}$ Ibid above

${ }^{69}$ Rule 16 of United Nations Standard Minimum Rules for the Administration of Juvenile Justice ("The Beijing Rules") Adopted by General Assembly resolution 40/33 of 29 November 1985

${ }^{70}$ Law of the Child Act (Juvenile Court Procedure) 2016
}

Labouring on the importance of the social enquiry report in sentencing and in the position of international law, there is a gap of asserting social enquiry report in our child law and in prescribing it as mandatory in all criminal proceedings against the child. Living the decision of when or where to consider social enquiry report to the court might lead to improper sentencing of the child offender or lack of uniformity in sentencing child offenders from one case to the other. Furthermore, a social enquiry report makes it easy for the court to craft a proper sentence;the absence of it makes it difficult for the court to craft a proper sentence as required by the law.

\section{CONCLUSION}

The international legal instruments require States to establish mechanisms that take into account the principles of sentencing, namely: proportionality, maintaining and strengthening family relationships, rehabilitation and reintegration of the child offender in the society, least restrictive, and consideration of other essential substances such as social inquiry report. The sentencing framework of the Child Act and its Rules in part reflects the requirements of international legal instruments law. The practical challenge of the Act includes the fact that the Act does not make the consideration of key principles and social inquiry reports mandatory before passing sentence to a child offender. ${ }^{72}$ However, the Juvenile Court Rules clearly provides for mandatory consideration of the key principles and social inquiry report. ${ }^{73}$ Thus, the sentences for child offenders are limited to those which expose the considerations of both the key principles and the social inquiry report as it has been provided under the Rule ${ }^{74}$ rather than the Act. This, however, is a challenge. Courts have to consider principles of sentencing as provided by the international legal instruments, the Act and the Rule. Meanwhile,the mind of the court has to be extended to consider the

\footnotetext{
${ }^{71}$ S V Jansen 1975(1) SA 425 A

72 On social Inquiry report, see section 100A (2), Law of the Child Act Cap.13 R.E 2019, furthermore principles of sentencing are not specifically prescribed anywhere in the Act.

${ }^{73}$ Rule 49 (1) and (2) of Juvenile Court Rules, 2016

${ }^{74}$ Ibid Rule 49 (1) and (2) of Juvenile Court Rules, 2016
} 
imposition of sentences that are the best to the interests of the convicted child.

\section{BIBLIOGRAPHY}

Bala, N. "R v. M (J.J.). "The Rehabilitative Ideal for Young Offenders - Back to the Past?" (1993) 20 C.R. (4th) 308 at 309.

Kilekamajenga, Ntemi N. "Learning from contemporary examples in Africa: Referral mechanisms for restorative justice in Tanzania." South African Crime Quarterly 63 (2018): 17-26.

Lilly, J. Robert, Francis T. Cullen, and Richard A. Ball. Criminological theory: Context and consequences. Sage publications, 2011.

Maganga, Christina S. "Administration of Juvenile Justice in Tanzania A study of its compatibility with International Norms and Standards." PhD diss., Lund University, 2005.

Mandopi, Kevin. "The Sentencing Process to The Convicted Juvenile Offender: The Judicial Officers Need Attention." Journal Of Asian and African Social Science and Humanities 1, No. 2 (2015): 62-84.

Moffitt, Terrie E. "Adolescence-limited and lifecourse-persistent antisocial behavior: a developmental taxonomy." Psychological review 100, no. 4 (1993): 674.

Suffredini, Brian R. "Juvenile gunslingers: A place for punitive philosophy in rehabilitative juvenile justice.” BCL Rev. 35 (1993): 885.

Tata, Cyrus, Nicola Burns, Simon Halliday, Neil Hutton, and Fergus McNeill. "Assisting and advising the sentencing decision process: The pursuit of 'quality' in pre-sentence reports." The British Journal of Criminology 48, no. 6 (2008): 835-855.

Wright, Kevin N. Family Life, Delinquency and Crime: A Policymaker's Guide: Research Summary. US Department of Justice, Office of Justice Programs, Office of Juvenile Justice and Delinquency Prevention, 1994.

12 This work is licensed under a Creative Commons Attribution 4.0 International License. 